The Egyptian Journal of Hospital Medicine (July 2011) Vol., 44: 318 - 324

\title{
Adiponectin and interlukin-10 in patients with liver diseases before and after liver transplantation
}

\author{
Abdelgawad A. Fahmi ${ }^{1}$, Mohamed A. El-Desouky², Mohamed M. El Gamal' ${ }^{3}$, Azza E. \\ Zidan ${ }^{3 *}$. \\ Determents of Organic Chemistry ${ }^{\mathbf{1}}$ and Biochemistry ${ }^{\mathbf{2}}$ Faculty of Science, Cairo University, \\ Determents of Immunology and Microbiology, Military Medical Academy ${ }^{\mathbf{3}}$, Egypt. \\ *Corresponding author E-mail: azza_icwater@yahoo.com
}

\begin{abstract}
Background/Aims: Hepatitis C virus (HCV) infection is a global blood-borne disease with the highest prevalence in Egypt. This study was carried out to evaluate the prevalence of adiponectin, Interleukin-10 levels in liver diseases and to identify the potential role of adipocyte derived adiponectin in patients with end stage before and after liver transplantation.
\end{abstract}

Subject \& method: The study population included 69 subjects classified as follow: Control group (G1) healthy individuals, group (G2) Anti $\mathrm{HCV}+\mathrm{ve} \& \mathrm{HCV}$ RNA +ve by PCR, group (G3) Anti-HCV +ve \&HCV RNA-ve by PCR and liver transplantation group (G4) patients underwent orthotropic liver transplantation; before liver transplantation (G4b) and after one week of liver transplantation (G4a).

Result: Adiponectin levels showed highly significant decrease in G2 (P <0.002), G3 showed insignificant decrease $(\mathrm{P}<0.6), \mathrm{G} 4 \mathrm{~b}$ showed highly significant increased $(\mathrm{P}<0.0001)$ and $\mathrm{G} 4 \mathrm{a}$ showed insignificant decrease $(\mathrm{P}<0.08)$ compared with control group G1. IL-10 levels showed highly significant increase in patients groups $(\mathrm{G} 2, \mathrm{G} 3, \mathrm{G} 4 \mathrm{~b}$ and $\mathrm{G} 4 \mathrm{a})$ as compared with control group $(\mathrm{P}<0.0001)$.

Conclusion: Adiponectin and IL-10 may be used as biomarker and/or a mediator of inflammatory states in liver diseases in patients with chronic hepatitis C. We suggest that high adiponectin and IL-10 levels in chronic liver disease before liver transplantation might reflect one of the body's anti-inflammatory mechanisms in chronic liver diseases.

Keywords: Chronic hepatitis C, Hepatitis C virus, adiponectin, Interleukin-10, liver transplantation.

\section{Introduction}

Hepatitis $\mathrm{C}$ virus (HCV) has chronically infected more than $3 \%$ world population especially in developing countries. HCV infection accounts for approximately $15-20 \%$ cases of acute hepatitis and $50-80 \%$ cases of chronic hepatitis with viral persistence being at risk to develop liver inflammation, fibrosis, cirrhosis and HCC. In 40 $60 \%$ of $\mathrm{HCV}$ infected individuals persistent infection is mainly associated with liver cirrhosis and steatosis leading to HCC with mortality rate of $2-5 \%$ per year (Saba et al ., 2011). Liver transplantation is widely accepted as an effective therapeutic modality for a variety of irreversible acute and chronic liver diseases for which no satisfactory therapy is available (Kuno \& PierreAlain, 2010). Adipose tissue, besides serving for energy storage, actively secretes adipokines such as leptin and adiponectin. Adiponectin is a 247 amino acid adipokine that has been shown to improve insulin sensitivity in muscle and liver by enhancing free fatty acid oxidation (Perdo et al., 2010). Adiponectin was considered to be synthesized exclusively by adipocytes; however, recent data show that it is also produced by other cell types (Crawford et al., 2010). Adiponectin is also known as 30KD adipocyte complementrelated protein; Acrp30 (Kaser et al., 2005). Two adiponectin receptors types were recently identified adipoR1 abundantly expressed in muscle, whereas adipo R2 is predominantly expressed in the liver (James, 2008). Interleukin10 (IL-10) is produced by various cell types including $\mathrm{T}$ and $\mathrm{B}$ cells, monocytes, and macrophages. This cytokine is highly pleiotropic in its biological activity that includes: inhibition of the synthesis of several cytokines, including IL-1, IL-2, IL-3, IL-6, IL-8, IL-12, tumor necrosis factor $\alpha$ (TNF- $\alpha)$, and interferon $\gamma$ (IFN- 
$\gamma)$;immunosuppressive effects on monocytes/macrophages as well as immunostimulatory activity on a broad range of cells types, including $\mathrm{T}$ cells, B cells, and mast cells (Vera \&Pedro et al., 2010). IL-10 plays a key role in the regulation of cellular immune responses in HCV infection (Kazunori et al., 2006). This study was carried out to evaluate the prevalence of adiponectin, Interleukin-10 levels in liver diseases and to identify the potential role of adipocyte derived adiponectin in patients with end stage before and after liver transplantation.

\section{Subject and method}

Study population and data collection

Samples were collected between January 2009 to January 2010 from Gastroenterology and Endoscopy Department of MAADI Military Hospital. The study population included 69 subjects classified as follow: Control group (G1) included 12 (7males and 5 females) healthy individuals. Group (G2) included 19 (15 males and 4 females) Anti HCV +ve \& HCV RNA +ve by PCR, group (G3) included 19 (10 males and 9 females) Anti-HCV +ve \&HCV RNA -ve by PCR. They were diagnosed as HCV positive with chronic liver disease on clinical, laboratory and Ultrasonographic basis. Liver transplantation group (G4) included 19 (males) underwent orthotopic liver transplantation, before liver transplantation; (G4b) and after one week of liver transplantation (G4a).

All subject involved in this study were matched in age (40 - 60 years), Full history taking, clinical examination and laboratory investigations including hepatitis markers were determined using commercial enzyme immunoassay kits (AXSYM System, Abbott, and Wiesbaden, Germany) and HCV RNA BY PCR was performed by Roche COBAS qualitative, quantitative COBAS or TaqMan reversetranscriptase polymerase chain reaction (RTPCR) assay (Roche Diagnostics, Branchburg, NJ) a detection limit of 100 copies /ml (Sybio, Shanghai, China) and HBV DNA was detected in sera by PCR, an amplification quantitative assay and in accordance with the procedure of Cobas Amplicor HBV Monitor Test (Roche Molecular Systems, Branchburg, NJ, USA). The linear range of the assay is $2 \times 102-2 \times 105$ copies/mL HBV DNA. The diagnosis of cirrhosis was based on the clinical and laboratory findings (hypoalbuminemia, prolongation of prothrombin time, hyperbilirubinemia, and presence of ascites or other findings of portal hypertension).

The following investigations were done for all patients groups, liver enzymes (AST, ALT and ALP), kidney profile (urea, creatinine and uric acid), Albumin, total protein, bilirubin, fasting blood sugar and LDH were done using an immunoturbidimetric high-sensitivity assay on a Hitachi 911 analyzer (Roche Diagnostics, Indianapolis, Ind), hemoglobin ( $\mathrm{Hb})$ concentration and platelet count were done by Coulter Gen S system 2(Beckman).

Abdominal ultrasound: Each patient underwent abdominal ultrasonography using a $3.0 \mathrm{MHz}$ curved array transducer and a standard Acuson Sequoia 512 system (Acuson, Mountain View, CA, USA). Liver transplanted patients received induction immunotherapy with Orthoclone OKT3 followed by triple immunosuppression therapy with cyclosporine, azathioprine and steroids. Patients were converted to tacrolimus for recurrent or severe rejection episodes or for side effects of cyclosporine

\section{Blood collection}

Serum; morning fasting blood samples were collected from all subjects into Vacutainer tubes left to clot for 20 minutes at $37 \mathrm{oC}$ and then centrifuged at $3000 \mathrm{rpm}$ for 15 minutes and the samples were stored in aliquots at -80 0C until assayed. Peripheral blood; was drawn after an overnight fast and EDTA plasma was obtained for determination of $\mathrm{Hb}$ and platelet count $(2 \mathrm{ml})$.

\section{Measurement of serum Adiponectin and Interleukin-10 levels}

Adiponectin and IL-10 serum levels were measured with enzyme linked immunosorbent assay (ELISA) (B-Bridge International, San Jose, CA, USA); according to manufacturer's manual. The calibration curves were constructed by plotting the net average absorbances of the standards on the $\mathrm{Y}$-axis and the concentrations on the $\mathrm{X}$-axis using the logit-log function.

\section{Statistical analysis}

Standard computer program SPSS for Windows, release 13.0 (SPSS Inc, USA) was used for data entry and analysis. All numeric variables were expressed as mean \pm standard deviation (SD), $\mathrm{p} \leq$ 0.05 was considered to be statistically significant using Kruskal - wallis test. Comparison of 
different variables in various groups was done using Mann Whitney test for nonparametric variables. Graphic presentation of the results was also done.

\section{Results}

Adiponectin levels in healthy control (G1) ranged from 4 to $10 \mathrm{ng} / \mathrm{ml}$ with a mean value of $(7.6 \pm$ $2.5 \mathrm{ng} / \mathrm{ml}$ ), In (G2) Adiponectin levels ranged from 3 to $10 \mathrm{ng} / \mathrm{ml}$ with a mean value of $(5.7 \pm$
$2.6 \mathrm{ng} / \mathrm{ml}),(\mathrm{G} 3)$ ranged from 5 to $12 \mathrm{ng} / \mathrm{ml}$ with a mean value of $(7.4 \pm 2.7 \mathrm{ng} / \mathrm{ml})$, $(\mathrm{G} 4 \mathrm{~b})$ ranged from 25 to $50 \mathrm{ng} / \mathrm{ml}$ with a mean value of $(38.6 \pm$ $9.6 \mathrm{ng} / \mathrm{ml})$ and $(\mathrm{G} 4 \mathrm{a})$ ranged from 2 to $10 \mathrm{ng} / \mathrm{ml}$ with a mean value of $(5.7 \pm 2.9 \mathrm{ng} / \mathrm{ml})$. Adiponectin levels showed highly significance decrease in G2 (P <0.002), G3 showed insignificant decrease $(\mathrm{P}<0.6), \quad \mathrm{G} 4 \mathrm{~b}$ showed highly significant increased $(\mathrm{P}<0.0001)$ and $\mathrm{G} 4 \mathrm{a}$ showed insignificant decrease $(\mathrm{P}<0.08)$ compared with control group G1 fig (1).

Fig (1): Sera mean levels of Acrp30 ng/ml in control and different studied groups.

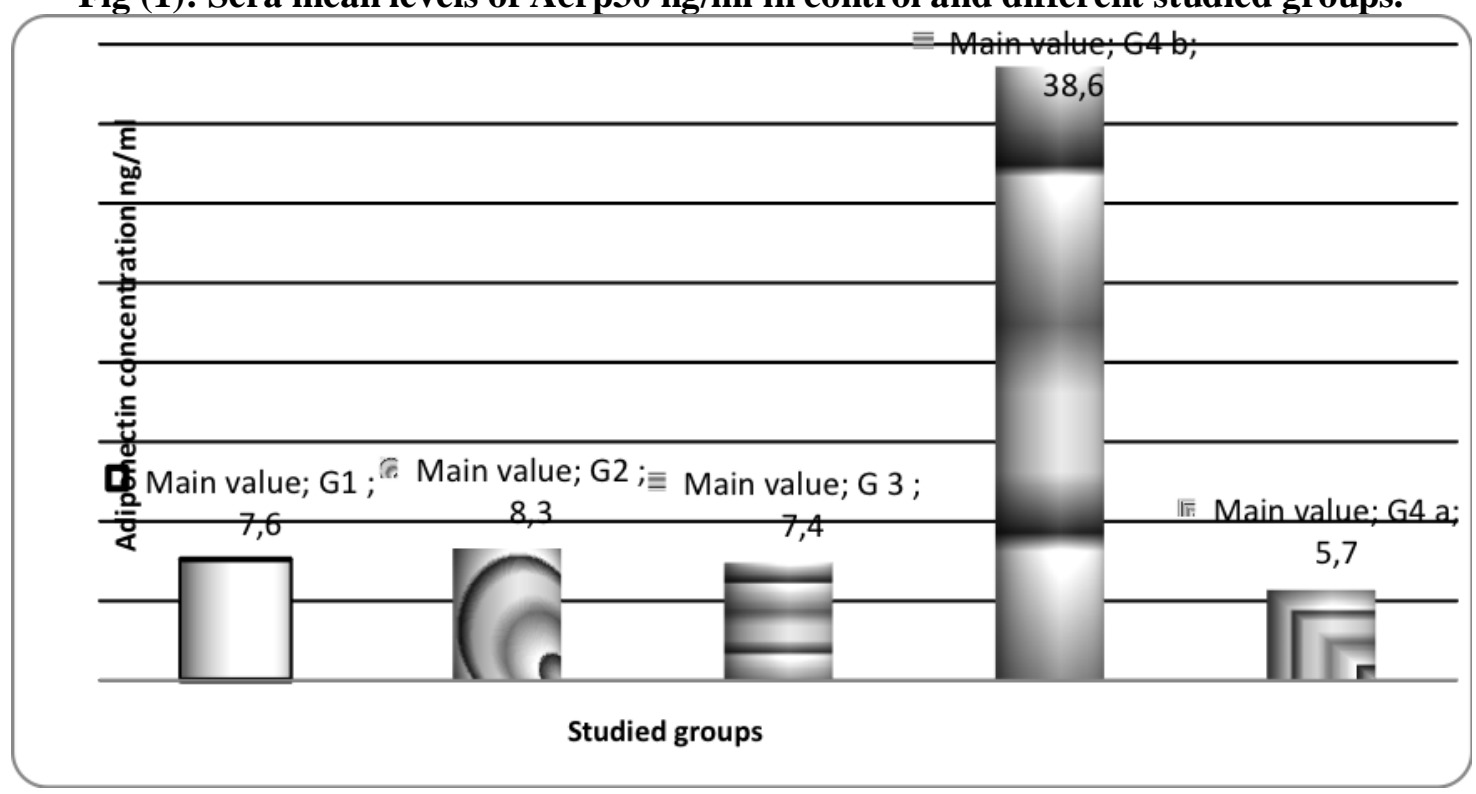

IL-10 levels in control group (G1) ranged from 1.1 to $2.2 \mathrm{ng} / \mathrm{ml}$ with a mean value of $(1.40 \pm 0.35 \mathrm{ng} / \mathrm{ml})$, (G2) ranged from 2.2 to $3.6 \mathrm{ng} / \mathrm{ml}$ with a mean value of $(2.2 \pm 0.8 \mathrm{ng} / \mathrm{ml}),(\mathrm{G} 3)$ ranged from 2 to $3.9 \mathrm{ng} / \mathrm{ml}$ with a mean value of $(2.7 \pm 0.4 \mathrm{ng} / \mathrm{ml}),(\mathrm{G} 4 \mathrm{~b})$ ranged from 2.9 to $7.5 \mathrm{ng} / \mathrm{ml}$ with a mean value of $(4.4 \pm 1.6$ $\mathrm{ng} / \mathrm{ml})$ and (G4a) ranged from 2 to $3.6 \mathrm{ng} / \mathrm{ml}$ with a mean value of $(2.6 \pm 0.4 \mathrm{ng} / \mathrm{ml}$. IL-10 levels showed highly significant decrease in patients groups $(\mathrm{G} 2, \mathrm{G} 3$ and G4a) as compared with control group $(\mathrm{P}<0.0001)$ and showed highly significant increased $(\mathrm{P}<0.0001)$ in G4b fig (2)

Fig (1): Sera mean levels of IL-10 ng/ml in control and different studied groups.

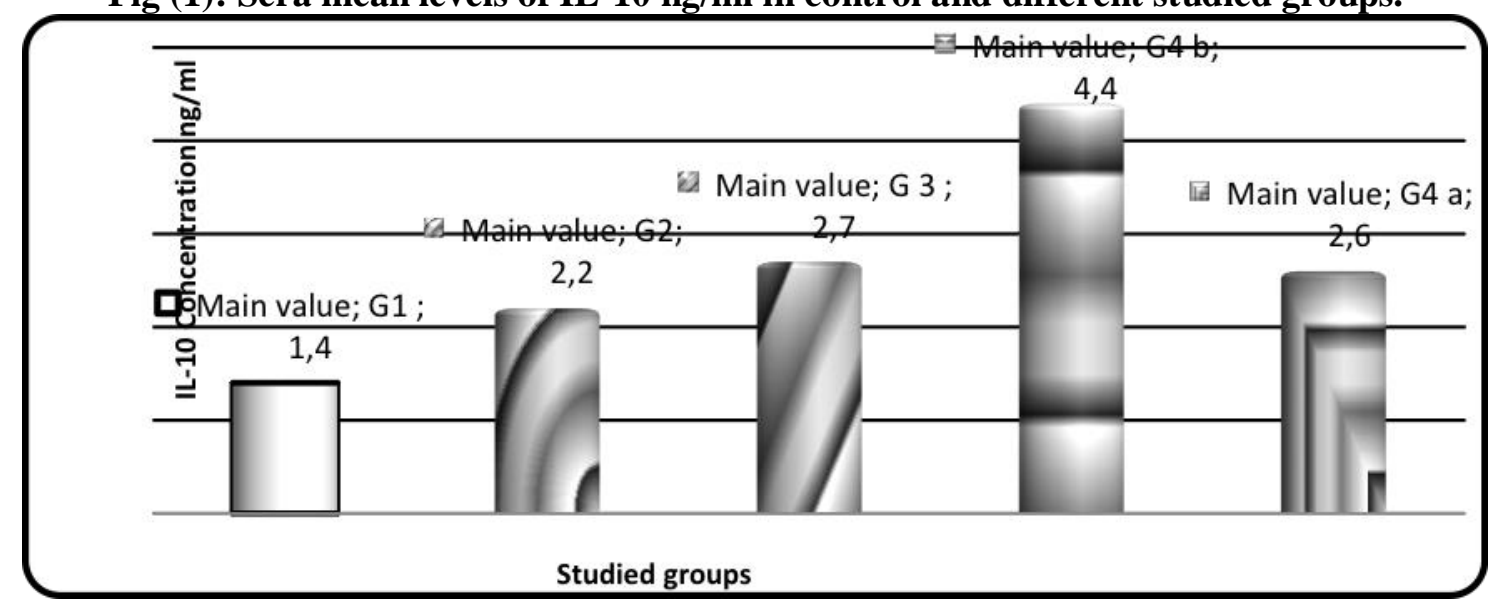

Biochemical Laboratory parameters of the studied group and healthy control subject are shown in Table 1.Our study showed highly significantly elevated circulating liver enzyme (AST, ALT, ALP \& GGT) in 
Adiponectin and interlukin....

groups (G2b) and (G2a) compared to healthy subject (G1) and showed significantly decreased platelet in (G2a) $(\mathrm{P}<0.001)$.

Table 1: Biochemical characteristics of study patients and control subjects.

\begin{tabular}{cccccc}
\hline & $\begin{array}{c}\text { G1 Control } \\
(\mathrm{n}=12)\end{array}$ & $\begin{array}{c}\mathrm{G} 2 \\
(\mathrm{n}=19)\end{array}$ & $\begin{array}{c}\mathrm{G} 3 \\
(\mathrm{n}=19)\end{array}$ & $\begin{array}{c}\text { G4b } \\
(\mathrm{n}=19)\end{array}$ & $\begin{array}{c}\text { G4a } \\
(\mathrm{n}=19)\end{array}$ \\
\hline Adiponectin level (ng/ml) & $7.6 \pm 2.5$ & $5.7 \pm 2.5$ & $7.4 \pm 2.7$ & $38.6 \pm 9.6$ & $5.7 \pm 2.9$ \\
IL-10 level (ng/ml) & $1.4 \pm 0.3$ & $2.2 \pm 0.8$ & $2.7 \pm 0.4$ & $4.4 \pm 1.6$ & $2.6 \pm 0.4$ \\
AST activity (U/L) & $23.6 \pm 6$ & $36.6 \pm 15$ & $35.7 \pm 8.9$ & $37.7 \pm 11$ & $44.1 \pm 16.9$ \\
ALT activity (U/L) & $25.3 \pm 9.4$ & $30.3 \pm 12$ & $30.2 \pm 11.6$ & $41.3 \pm 13.4$ & $46.8 \pm 11.1$ \\
GGT activity (U/L) & $13.17 \pm 2.6$ & $50.5 \pm 33.8$ & $78 \pm 18$ & $79.6 \pm 37.9$ & $52.8 \pm 24.2$ \\
Albumin level g/dL & $3.9 \pm 0.4$ & $3.2 \pm 0.9$ & $2.24 \pm 1.2$ & $2.9 \pm 0.8$ & $3.94 \pm 0.4$ \\
ALP activity (U/L) & $102.5 \pm 24.1$ & $85.1 \pm 23.9$ & $87.7 \pm 18$ & $63 \pm 25.3$ & $132.6 \pm 36.8$ \\
Urea level (mg/dl) & $26.2 \pm 6.5$ & $25.9 \pm 9.4$ & $19.7 \pm 4.5$ & $35.4 \pm 12.7$ & $39.4 \pm 17$ \\
Creatinine level (mg/dl) & $0.8 \pm 0.1$ & $0.8 \pm 0.2$ & $0.9 \pm 0.2$ & $1.11 \pm 0.8$ & $1.0 \pm 0.3$ \\
FBS level (mg/dl) & $82.75 \pm 6.4$ & $81.7 \pm 14.8$ & $88 \pm 11.2$ & $87.1 \pm 9.2$ & $91 \pm 5.9$ \\
Total Protein mg/dl & $7.6 \pm 0.5$ & $7.3 \pm 1.4$ & $7.3 \pm 0.6$ & $7.4 \pm 0.9$ & $6.0 \pm 1.0$ \\
Hemoglobin (g/dl) & $13.0 \pm 1.24$ & $12.9 \pm 2.5$ & $11.2 \pm 1.70$ & $10.4 \pm 2.4$ & $9.0 \pm 1.2$ \\
Platelets count & $252.2 \pm 20.9$ & $225 \pm 45.8$ & $144.9 \pm 42.8$ & $144.9 \pm 42.8$ & $196.4 \pm 14.2$ \\
LDH u/l & $472 \pm 79.2$ & $471.8 \pm 88.3$ & $550 \pm 70.7$ & $499 \pm 70.2$ & $546.1 \pm 65.7$ \\
\hline
\end{tabular}

AST, aspartate aminotransferase; ALT, alaline aminotransferase; GGT, $\gamma$-glutamyltranspeptidase and data are expressed as mean \pm SD.

\section{Discussion}

The significance finding in this study is that the chronic HCV patients with viremia (G2) showed significant reduced circulating adiponectin levels compared with healthy subject $(\mathrm{G} 1) \quad(\mathrm{P}<0.002)$ and insignificant reduced circulating adiponectin levels $(\mathrm{P}<0.6)$ in $(\mathrm{G} 3)$ compared to those with viremia $(\mathrm{G} 2)(\mathrm{P}<0.86)$ This result agree with that done by Emmanuel \& George, (2006), who found that decreased adiponectin sera levels have been detected initially in patients with chronic $\mathrm{HCV}$ infection .Hypothesized that dysregulation of adiponectin and adiponectin receptor system could contribute to the development of steatosis in chronic hepatitis C virus patients. Durante et al., (2006) reported that reduced adiponectin levels may be involved in the pathogenesis of steatosis, which in turn accelerates progression of fibrosis in chronic HCV patients.

Our data showed that circulating adiponectin levels were significantly elevated in (G3) compared to those with viremia $(\mathrm{G} 2)(\mathrm{P}<0.001)$. Both pathogenic groups suffer from steatosis with chronic. Adiponectin protein expression was mainly found in hepatic endothelial cells of liver sinusoids and portal vessels. Patients before liver transplantation (G4b) revealed statistically significance elevation of adiponectin levels compared to healthy control group (G1) $(\mathrm{P}<0.0001)$, patients before liver transplantation suffer from cirrhosis which increases circulating adiponectin levels. Sato et al., 2005 reported that the serum concentration of adiponectin is regulated by the balance between secretion from adipocytes and excretion by the kidney and liver. In patients with liver cirrhosis, the serum adiponectin levels known to be elevated due to decreased hepatic extraction of adiponectin from the circulation. Sohara et al., (2005) reported that increased plasma levels of adiponectin in liver cirrhosis could be because of either increased production or reduced metabolism.

The difference between circulating adiponectin levels in patients before and after liver transplantation were significantly reduced adiponectin levels after liver transplantation ( $\mathrm{P}$ $<0.001)$ these results suggest the possibility that low adiponectin levels are a feature after liver transplantation independent of age and sex could be used for follow up.

Our study showed highly significantly elevated circulating liver enzyme (AST, ALT \& GGT) in groups (G2), (G4b) and (G4a) compared to healthy subject (G1) (P<0.0001 for AST), (P $<0.0001$ for GGT) and for ALT $(\mathrm{P}<0.0001)$. 


\section{Abdelgawad Fahmi... et al}

While (G3) indicate insignificant elevated circulating liver enzyme compared to healthy subject $(\mathrm{G} 1)(\mathrm{P}<0.4)$.

Non-alcoholic fatty liver disease (NAFLD) is a common liver pathology that begins from simple steatosis and then progresses to steatohepatitis and ends with cirrhosis or liver failure. While simple steatosis is accepted as a benign state, steatohepatitis, because of elevated liver enzymes [alanine aminotransferase (ALT) and aspartate aminotansferase (AST)] and certain metabolic abnormalities such as diabetes, obesity, dyslipidemia, hypertension and insulin resistance is assessed as a serious condition. Some nonalcoholic steatohepatitis (NASH) patients can have normal aminotransferase levels or conversely some patients with high liver enzymes may not have steatohepatitis. It has emerged that some NAFLD patients may not fulfill all criteria concerned with metabolic syndrome and do not have insulin resistance. NASH can occur without an increase in liver enzyme levels and that there may not be progression of NASH in fatty liver patients with high liver enzymes (Hüseyin SU et al, 2009). Analysis of serum ALT activity levels is routinely used for detecting liver injury, a biomarker that has been in use for more than 50 years (BJÖRN et al., 2009).

In patients with chronic hepatitis $\mathrm{C}$ infection an imbalance in Th1 and Th2 cytokine production is implicated in disease progression of chronic $\mathrm{HCV}$ (Martin-Blondel et al., 2009). Interleukin-10 was first described as cytokine synthesis inhibitory factor (CSIF), which was produced by mouse Th2 cells and inhibited activation and cytokine production by Th1 cells. The ability of IL-10 to inhibit cytokine production by both $\mathrm{T}$ cells and NK cells was found to be indirect, via inhibition of accessory cell (macrophage/ monocyte) function (Camila et al., 2011).

IL-10 production by peripheral blood mononuclear cells was insignificantly elevated in (G3) compared to those with viremia (G2) (P $<0.2)$, IL-10 levels were significantly elevated in (G2), (G3), (G4b) and (G4a) compared to healthy control (G1) (P <0.0001).

Patients with chronic HCV infections show enhanced serum IL-10 concentration and T-cells IL-10 production in response to stimulation with HCV Core protein (Martin-Blondel et al., 2009).

The difference between IL-10 levels in patients before and after liver transplantation were significantly reduced IL-10 levels after liver transplantation $\mathrm{G} 4 \mathrm{a}(\mathrm{P}<0.0001)$ where after one week of liver transplantation IL-10 return to its normal value.

An immediate/ early post-transplantation increase in systemic IL-10 levels, which quickly returned to normal values, has been reported and was associated with possible activation of the graft's macrophages. IL-10 may be related to the development of hepatitis $\mathrm{C}$ chronicity. After liver transplantation for hepatitis $\mathrm{C}$, production of cytokines is not exclusively driven by disease recurrence but may be altered by confounding factors, including graft damage, allo-specific immune response and immunosuppression (Patricia et al., 2001).

In conclusion adiponectin and IL-10 may be used as biomarker and/or a mediator of inflammatory states in liver diseases in patients with chronic hepatitis $\mathrm{C}$. We suggest that high adiponectin and IL-10 levels in chronic liver disease before liver transplantation might reflect one of the body's anti-inflammatory mechanisms in chronic liver diseases. Low adiponectin levels are a feature after liver transplantation and could be used for follow up after liver transplantation.

Recommendation: using adiponectin as biomarker and/or a mediator of inflammatory states in liver diseases before and after liver transplantation.

Acknowledgements: The authors acknowledge the assistance of the research fellows and the scientific staff at the Gestroentrology and Endoscopy dep of ElMAADI Military Hospital.

\section{References}

BJÖRN G, INGALILL R, ANNA-KARIN L, JESPER JH, HÅKAN B A, PER L, ANNA-LENA $B$ and IAN C (2009): Detection of the mitochondrial and catalytically active alanine aminotransferase in human tissues and plasma. Int J. Mol Med., 23(5):62131.

Camila AF, Neuza MAlcantara-Neves, Leila DA, Nivea BS, Lain CP, Philip JC, Laura CR and Maurício LB (2011): Evidence for a modulatory effect of IL-10 on both Th1 and Th2 cytokine production: the role of the environment. Clin Immunol., 139(1):57-64.

Crawford LJ, Roy P, Susan P, Treen CM, and Alexandra EI (2010): Adiponectin is produced by lymphocytes and is a negative regulator of granulopoiesis; J Leukoc Biol., 88(4):807-11.

Durante M, Zampino $R$ and Marrone A (2006): Hepatic steatosis and IR are associated with serum imbalance of adiponectin/ TNF- $\alpha$ in chronic HCV patients. Aliment Pharmacol. Ther., 1:24(9)1349-57. 


\section{Adiponectin and interlukin....}

Emmanuel T\& George V (2006): The evolving role of Leptin and adiponectin in chronic liver disease. Am J Gastroenterology., 101(11):2629-40.

Hüseyin SU, Selim GN, Macit G, and Zeynep B (2009): Non-alcoholic steatohepatitis with normal aminotransferase values. World J Gastroenterol., 21; 15(15):1863-8.

James RS (2008): Endocrine functions of adipose tissue: focus on adiponectin. Clin Cornerstone ., 9(1):32-8.

Kaser S, Moschen A, Kaser A, Ludwiczek O, Ebenbichler CF, Vogel W, Jaschke W, Patsch JR and Tilg $H$ (2005): Circulating adiponectin reflects severity of liver disease but not insulin sensitivity in liver cirrhosis. J. Intern Med.; 258(3):274-80.

Kazunori K, Hirofumi U, Katsuhiro H, Yuka T, Hiroyuki N, Robert, Sherri O. Stuver, , Akio I and Hirohito T (2006): Interleukin-10 or tumor necrosis factor-alpha polymorphisms and the natural course of hepatitis $\mathrm{C}$ virus infection in a hyperendemic area of Japan; Cytokine., 34(1-2):24-31

Kuno L, Pierre-Alain C (2010): History of hepatic surgery, Surg Clin North Am; 90(4):655-64.

Martin-Blondel G, Gales A, Bernad J, Cuzin L, Delobel P, Barange K, Izopet J, Pipy B and Alric L (2009): low interleukin-10 production by monocytes of patientswith a self-limiting hepatitis $\mathrm{C}$ virus infection. Alric Journal of Viral Hepatitis, 16; 485491
Patricia AS, Sander SF, Sukru E, Thomas F, Myron ES, Charles MM and Peter B (2001): Recurrence of hepatitis $\mathrm{C}$ after liver transplantation is associated with increased systemic IL-10 levels. Mediators Inflamm., 10(1):37-41.

Perdo M, Muriello B, Fred P, Vincent M, Gerrard W and Peter Vollenweider (2010): Distribution of plasma levels of adiponectin and leptin in an adult Caucasian population. Clin Endocrinol (Oxf) , 72(1):38-46.

Saba K, Shah J and Asim P (2011): Sequence variability of $\mathrm{HCV}$ Core region: Important predictors of $\mathrm{HCV}$ induced pathogenesis and viral production. Infect Genet Evol., 11(3):543-56.

Sato S, Furuta K, Mishiro T, Miyake T, Kohge N, Akagi S, Adachi $K$ and KinoshitaY (2005): Serum adiponectin concentration in patients with hepatitis $\mathrm{C}$ virus. J Clin Gastroenterol., 39(8):744-5.

Sohara N, Takagi H, Kakizaki S, Sato K, and Mori M (2005): Elevated plasma adiponectin concentrations in patients with liver cirrhosis correlate with plasma insulin levels. Liver International 25: 28-32.

Vera C, Pedro C, Tiago QF, Catarina G, Pedro M, Carlos F, Luclia D, Rui MB, Manuel Vand Miguel G (2010): Biological activity of heterologous murine interleukin-10 and preliminary studies on the use of a dextrin nanogel as a delivery system. International Journal of Pharmaceutics, 15; 400(1-2):234-42. 


\section{نسبه الأدبيونكتين و الأنترلوكين (10) فى مرضى الكبد قبل وبعد زرع الكبا}

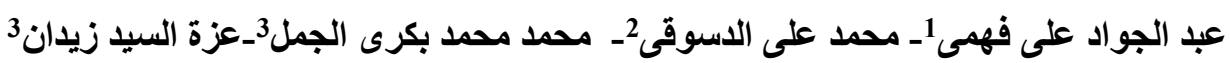

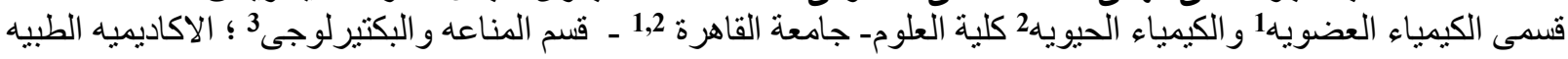
العسكرية3

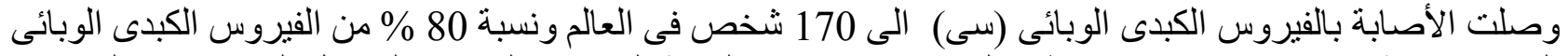

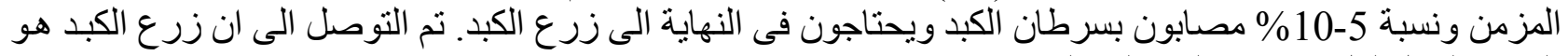

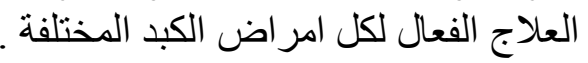

وقد أجريت هذه الدراسة على تسعون(69) شخص تم تقسيمهم إلى أربع مجمو عات كالآتى: المجموعة الأولى (ج1): 12 شخصا لايعانون من اية أمر اض وهذه عرفت بالمجموعة الضابطة. المجموعة الثانية (ج2): 19مريضا مصابين بالفيروس الكبدى الوبائى (سى) مع وجود الفيروس فى دمهر . (HCV-PCR positive) المجموعـة الثالثـه (ج3): 19مريضـا مصـابين بـالفيروس الكبـدى الوبـائى (سـى) مـع ع عدم وجـود الفيروس فـى دمهم (HCV-PCR negative) المجموعة الرابعة (ج 4) : 19مريضا تم زرع الكبد لهم هم:

$$
\begin{aligned}
& \text { ج4a } \\
& \text { (b) ج4أ: بعد اسبوع من زوع الزبل الكبد (a) } \\
& \text { وقد أظهرت النتائج ما يلى: }
\end{aligned}
$$

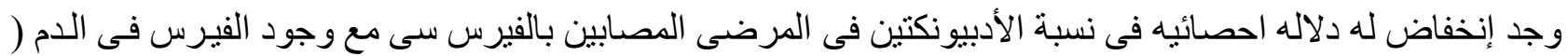

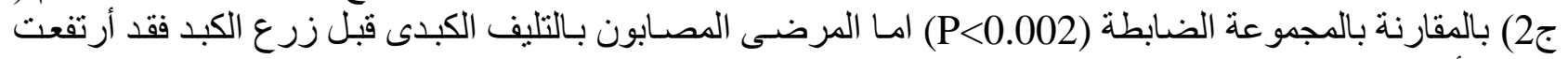

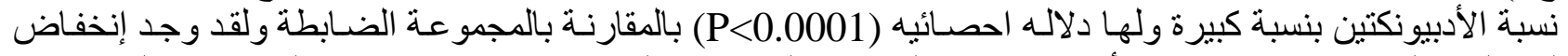

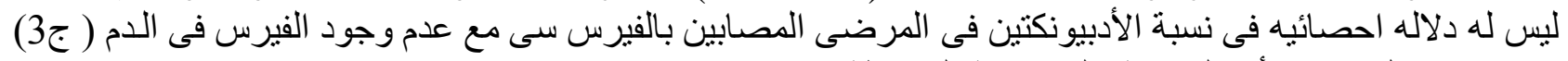

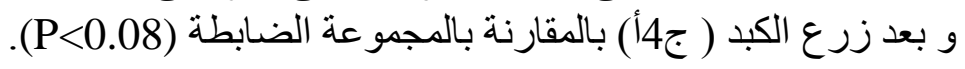

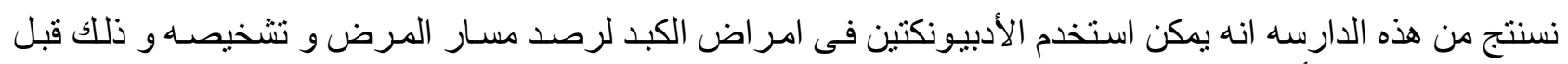

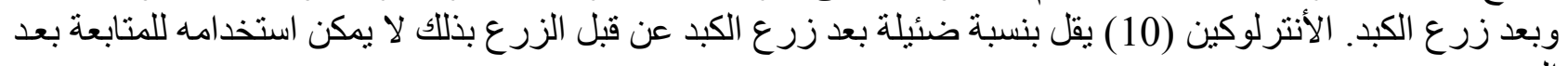
الزرع. 